\title{
Peluang pengajaran BIPA tingkat pendidikan tinggi di Timor Leste
}

\author{
Sri Rejeki ${ }^{\text {a, }}{ }^{*}$, Choirul Asari ${ }^{\text {b, } 2}$ \\ a aPendidikan Bahasa Inggris, Fakultas Keguruan dan Ilmu Pendidikan, Universitas Sebelas Maret \\ b Pengajar Bahasa Indonesia, Jakarta \\ ${ }^{1}$ srejeki60@gmail.com *; riebach87@gmail.com \\ *korespondensi penulis
}

\begin{tabular}{ll}
\hline Informasi artikel & \\
\hline Sejarah artikel: & \\
Diterima & 27 September 2019 \\
Revisi & I0 April 2019 \\
Dipublikasikan & 25 April 2019 \\
\hline
\end{tabular}

Kata kunci:

Bahasa Indonesia sebagai bahasa asing

Timor Leste

BIPA

\begin{abstract}
ABSTRAK
Tujuan dari artikel ini adalah untuk memaparkan peluang pengajaran bahasa Indonesia sebagai bahasa asing di tingkat pendidikan tinggi di Timor Leste serta motivasi mahasiswa Timor Leste mempelajari bahasa Indonesia. Bahasa Indonesia digunakan sebagai bahasa kerja dan bahasa pengantar di beberapa institusi pendidikan di Timor Leste. Penelitian ini merupakan penelitian deskriptif kualitatif dan menggunakan kuesioner untuk mengumpulkan data. Responden penelitian ini adalah II orang mahasiswa Timor Leste. Data menunjukkan bahwa tidak semua universitas memiliki mata kuliah Bahasa Indonesia namun mereka menggunakan Bahasa Indonesia sebagai bahasa pengantar akademik. Sebaliknya, hampir semua sekolah menengah atas di Timor Leste mengajarkan bahasa Indonesia bagi siswa mereka. Kedudukan bahasa Indonesia di Timor Leste juga mempengaruhi motivasi mahasiswa Timor Leste belajar bahasa Indonesia. Terdapat saran untuk penelitian selanjutnya serta instansi terkait untuk pengembangan bahasa Indonesia di Timor Leste.
\end{abstract}

Key word:

Indonesian as a foreign Language Timor Leste

IFL

\section{ABSTRACT}

The aim of this article is to describe about the chance to teach Indonesian language as a foreign language in higher institutions in Timor Leste and the motivation of the students in learning Indonesian language. Timor Leste people use Indonesian language as a working language and as a teaching language in some educational institution. This study is a descriptive qualitative research and uses questionnaire to gather the data. The respondent of this study are II Timorese students who study in higher education. The data shows that not all universities have Indonesian language course but they use Indonesian language as a teaching language in their institutions. On contrary, almost all senior high school in Timor Leste have Indonesian language course in their curriculum. The position of Indonesian language in Timor Leste als influences the motivation of the students to learn Indonesian language. Suggestions for further research and related institutions are provided.

\section{Copyright (C) 2019 Universitas Ahmad Dahlan}

\section{Pendahuluan}

Sebelum memisahkan diri dari Indonesia dan menjadi negara baru, Timor Leste merupakan salah satu daerah di Negara Kesatuan Republik Indonesia. Setelah resmi berpisah dari Indonesia pada tahun 2002, Timor Leste berusaha untuk memutuskan hubungan dengan Indonesia dan salah satunya adalah dengan menjadikan bahasa Portugis sebagai bahasa nasional mereka.

Namun, kenyataan berkata lain. Konstitusi Republik Demokratik Timor Leste (RDTL) menyebutkan bahwa ada dua bahasa nasional di Timor Leste, yaitu bahasa Tetun dan bahasa Portugis (pasal I3), serta mengakui bahasa Inggris dan bahasa Indonesia sebagai bahasa kerja (pasal I59) (Almeida dan Mariana, 20I4). Selain sebagai bahasa kerja, bahasa Indonesia juga berperan dalam pembangunan yang ada di Timor Leste, terutama di bidang pendidikan, perdagangan dan sosial budaya (Kusprabowo, 2008).

Bahasa Tetun dan bahasa Indonesia adalah bahasa yang paling banyak memiliki penuturnya dari pada bahasa Portugis. Meski kedua bahasa tersebut adalah bahasa kedua di Timor Leste, bahasa Indonesia tetap diajarkan di sekolah-sekolah karena bahasa Indonesia menjadi bahasa komunikasi antar pulau (Fox in Fox and Soares, 2003). Meski memiliki peran, pengguna bahasa Indonesia di Timor Leste sempat mengalami penurunan. Data 
statistik Timor Leste tahun 1990 menunjukkan bahwa generasi muda waktu itu memiliki kemampuan berbahasa Indonesia lebih baik daripada mereka yang berumur lebih dari 44 tahun (Jones dalam Fox dan Soares, 2003). Hal ini berbanding terbalik dengan apa yang terjadi pada tahun 2007. Data statistik Timor Leste menunjukkan bahwa sebanyak $38.2 \%$ orang Timor Leste masih bisa berbahasa Indonesia pada tahun 2007. Namun, jumlah tersebut mengalami penurunan jika dibandingkan tahun 200I, yakni sebesar $42.2 \%$. Terdapat penurunan sebanyak $4 \%$ dalam kurun waktu enam tahun (Kusprabowo, 2008).

Undang-Undang Nomor 24 tahun 2009 bab III bagian keempat tentang peningkatan fungsi bahasa Indonesia (Badan Pengembangan dan Pembinaan Bahasa, 2009) menjadi bahasa internasional pasal 44 menyebutkan bahwa (I) pemerintah meningkatkan fungsi bahasa Indonesia menjadi bahasa internasional secara bertahap, sistematis dan berkelanjutan, serta (2) peningkatan fungsi bahasa Indonesia menjadi bahasa internasional sebagaimana dimaksud pada ayat (I) dikoordinasi oleh lembaga kebahasaan. Lembaga Kebahasaan yang dimaksud adalah Badan Bahasa. Salah satu bentuk usaha yang dilakukan oleh Badan Bahasa untuk mengenalkan bahasa dan budaya Indonesia, khususnya di Timor Leste, adalah pemerintah Indonesia mengirimkan pengajar bahasa Indonesia bagi Penutur Asing (BIPA) ke Timor Leste.

Pengiriman tenaga pengajar BIPA ke Timor Leste merupakan langkah tepat yang dilakukan oleh pemerintah Indonesia karena selain dipelajari sebagai bahasa kerja, bahasa Indonesia juga diajarkan di SMA-SMA dan perguruan tinggi-perguruan tinggi yang ada di Timor Leste.

Masyarakat Timor Leste masih menggunakan bahasa Indonesia sebagai bahasa mereka, termasuk dalam kegiatan belajar mengajar. Masyarakat Timor Leste yang duduk di bangku sekolah dasar menggunakan dua bahasa di kelas enam, yakni bahasa Indonesia dan bahasa Tetun, sedangkan di kelas empat, mereka menggunakan tiga bahasa, yakni bahasa Portugis, bahasa Tetun dan bahasa daerah mereka (Development Studies Network, 2005).

Selain itu, sebagian besar sekolah menengah di Timor Leste menggunakan bahasa Indonesia karena mayoritas guru-guru di Timor Leste bersekolah di Indonesia dan tidak memahami bahasa Portugis (Patricio, 2009).

Bahasa Indonesia juga dipelajari oleh diplomatdiplomat yang ada di Timor Leste, baik itu yang bekerja di organisasi kemanusiaan, seperti KOICA, JICA dan UNDP, maupun oleh staf kedutaan (Rejeki, 2017). Hal ini menunjukkan bahwa bahasa
Indonesia masih memiliki pengaruh yang cukup besar bagi masyarakat Timor Leste (Patricio, 2009).

Yenny dalam Maulipaksi (2018) menyebutkan bahwa bahasa Indonesia cukup dikenal dan mulai banyak dipelajari di perguruan tinggi di Timor Leste. Selain itu, ATDIKBUD KBRI Dili juga berinisiatif untuk membentuk program BIPA lokal dengan harapan para pengajar tersebut dapat menjadi pengajar tanpa batasan waktu empat bulan (Maulipaksi, 2018).

Karena alasan tersebut, beberapa institusi pendidikan di Timor Leste mulai mengajarkan bahasa Indonesia, baik itu dengan nama mata kuliah bahasa Indonesia maupun dengan nama bahasa Melayu seperti yang ada di Institute of Business (IOB), Dili (Nirmalasari, 2017). Salah satu universitas yang ada di Timor Leste, yakni Universidade da paz (Unpaz), merupakan Universitas swasta tertua yang ada di Dili dan masih menggunakan bahasa Tetun dan bahasa Indonesia sebagai bahasa pengantar perkuliahan (Munady, 2016). Hal tersebut dilakukan karena bahasa Indonesia lebih mudah dipahami untuk mentransfer ilmu daripada bahasa lainnya yang ada di Timor Leste. Sebagai contoh lainnya adalah SMA Saint Petrus Comoro. SMA tersebut memiliki pelajaran bahasa Melayu namun yang diajarkan adalah bahasa Indonesia.

Dari alasan-alasan tersebut, tulisan ini bertujuan untuk mengungkapkan tentang pengajaran BIPA di Timor Leste dan alasan masyarakat Timor Leste mempelajari bahasa Indonesia. Untuk tulisan ini, penulis mendapatkan data dari laporan yang ditulis oleh para pengajar BIPA yang ditugaskan untuk mengajar di Timor Leste dan wawancara kepada pemelajar Timor Leste yang dipilih secara acak. Selain itu, penulis juga mendapatkan data dari artikel yang diunggah secara daring. Penelitian ini merupakan penelitian deskriptif kualitatif karena bertujuan untuk mendeskripsikan tentang pengajaran BIPA di Timor Leste serta motivasi masyarakat Timor Leste dalam mempelajari BIPA

\section{Metode}

Penelitian ini dilakukan di Dili, Timor Leste pada bulan Juli - Desember 20I7. Penelitian ini menggunakan pendekatan deskriptif kualitatif untuk menggambarkan data yang diperoleh dari responden berupa kalimat. Metode kualitatif diplih karena memberikan informasi terkini sehingga dapat memberikan manfaat ke pihak-pihak yang terkait. Penelitian ini menggunakan Google Form sebagai media kuesioner yang digunakan sebagai instrument untuk mendapatkan dan mengumpulkan data dari responden. Setelah data terkumpul kemudian 
diklasifikasikan dan dianalisa. Responden penelitian ini adalah mahasiswa Timor Leste yang sedang berkuliah di salah beberapa universitas di Timor Leste.

\section{Hasil dan pembahasan}

Di bagian ini, penulis akan membahas beberapa hal tentang pengajaran BIPA di Timor Leste, yaitu institusi-institusi yang mengajarkan bahasa Indonesia dan motivasi masyarakat Timor Leste belajar bahasa Indonesia.

Responden penelitian ini adalah mahasiswa Timor Leste yang sedang menjalani kuliah di Timor Leste. Demografi responden penelitian dapat dicermati pada grafik I di bawah ini. Mayoritas responden di penelitian ini adalah perempuan yakni dengan persentase $82 \%$ dan I8\% lainnya adalah laki-laki.

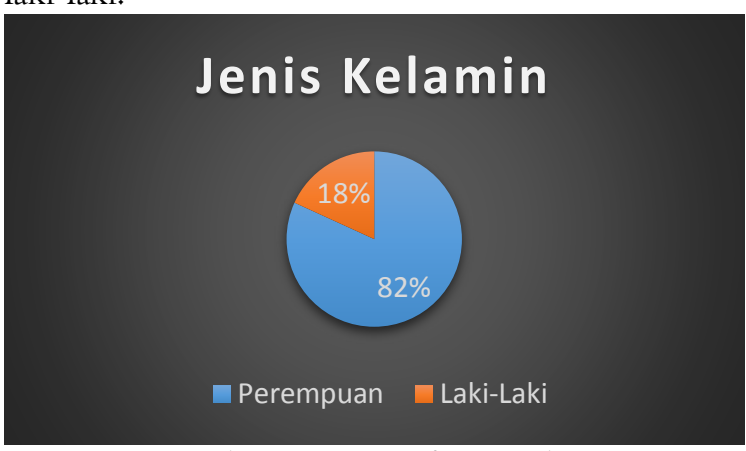

Gambar I. Demografi responden

Dari data yang diperoleh kemudian diklasifikasikan guna memudahkan dalam menganalisa data untuk mendapatkan informasi tentang institusi yang mengajarkan bahasa Indonesia di Timor Leste dan motivasi belajar bahasa Indonesia.

I. Institusi yang mengajarkan bahasa Indonesia di Timor Leste

Dari data yang diperoleh menyebutkan bahwa terdapat beberapa institusi di Timor Leste yang mengajarkan bahasa Indonesia kepada pemelajarnya. Berdasarkan data dari Badan Pengembangan dan Pembinaan Bahasa yang disampaikan di acara pembekalan pengajar luar negeri tahun 2016 di Hotel Santika Depok menyebutkan bahwa ada satu sasaran tempat yang mengajarkan BIPA di Timor Leste, yakni rumah budaya atau yang kemudian dikenal dengan Pusat Budaya Indonesia (PBI).

Berdasarkan hasil kuesioner yang diisi oleh responden menyebukan bahwa mereka sudah mempelajari bahasa Indonesia sejak mereka di SMA, bahkan ada yang mempelajari bahasa Indonesia sejak SMP. Tabel I menyajikan nama institusi di mana para pemelajar belajar tentang bahasa Indonesia.
Tabel I. Institusi yang mengajarkan bahasa Indonesia

\begin{tabular}{ccc}
\hline No & Nama Institusi & Sumber data \\
\hline I & Pusat Budaya Indonesia (PBI) \\
2 & Institute of Business (IOB), \\
& Dili \\
3 & Escola Secundaria Santo \\
& Antonio Teulale Bacau \\
4 & Eskola Pre-Sekundria Santo \\
& Antonio Teulale Bacau \\
5 & Eskola Sao Jose Operario \\
& Balide, Dili \\
6 & Escola Saint Madalena de & Wawancara \\
& Canossa & dengan \\
7 & Escola de Maio \\
8 & Eskola Saint Peter \\
9 & Eskola Saint Petrus Comoro \\
I0 & Eskola Katolik Dom Basilio do \\
\multicolumn{4}{c}{ Nascimento Manatuto } \\
II & Lniversida de Dili (UNDIL) \\
I2 & Escola Secundaria Antonio \\
& Baucau \\
\hline
\end{tabular}

Dapat dicermati pada tabel I bahwa terdapat II institusi di Timor Leste yang mengajarkan bahasa Indonesia di institusi-institusi tersebut. Dari sebelas institusi tersebut, satu institusi merupakan milik pemerintah Indonesia (PBI), dua institusi dalam bentuk pendidikan tinggi (universitas) dan sisanya dalam bentuk pendidikan menengah. Tidak seperti institusi pendidikan lainnya, Universida de Dili (UNDIL) mulai membuka mata kuliah bahasa Indonesia untuk mahasiswa mereka pada tahun 2018.

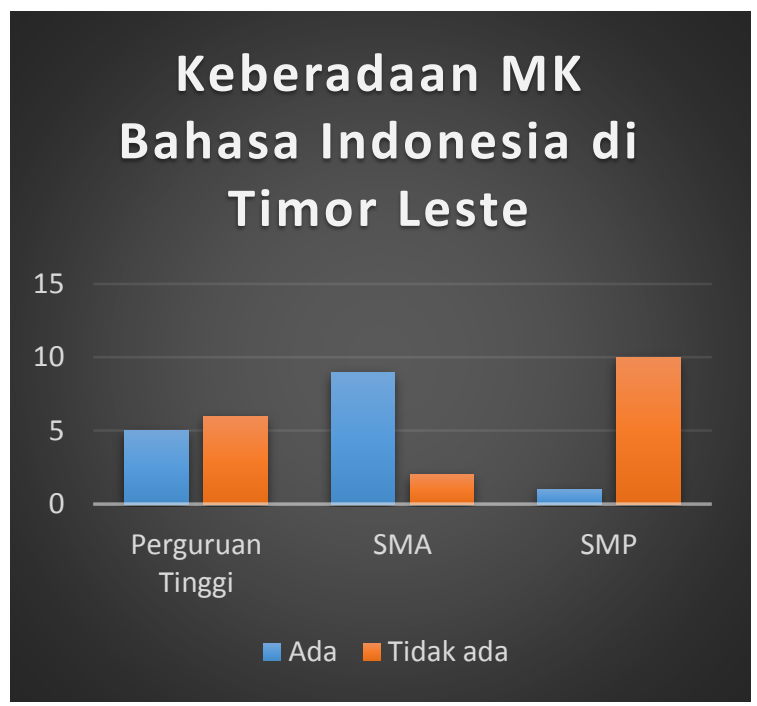

Gambar 2 Kedudukan mata kuliah Bahasa Indonesia di Timor Leste

Selain institusi-institusi tersebut, masih ada beberapa institusi lainnya yang mengajarkan bahasa Indonesia kepada pemelajar mereka. Institusi tersebut dapat dikatakan sebagai mitra Pusat Pengembangan Strategi dan Diplomasi Kebahasaan seperti pada Tabel 2 
Tabel 2 Tujuan pengajar bahasa Indonesia dari PPSDK

\begin{tabular}{ccc}
\hline No & Nama Institusi & Sumber \\
\hline I & Instituto Politecnico de & \\
& Betano (IPB), Same & \\
2 & East Timor Coffee Institute & \\
& (ETCI) Ermera & \\
3 & Escola NCS Gleno Distrik & Surat tugas dari \\
4 & Gleno, Ermera & PPSDK tahun \\
4 & Escola Secundaria Geral de & 20I7 \\
5 & Liquisa Distrik Liquisa & \\
& Escola Secundaria Catolica St. & \\
& Antonio Manatuto Distrik & \\
6 & Manatuto \\
& Escola Technico Distrik & \\
& Baucau &
\end{tabular}

Seperti yang tercantum pada tabel 2 tentang institusi yang juga mengajarkan bahasa Indonesia bahwa ada enam (6) institusi di Timor Leste yang tidak termasuk ke dalam tabel I yang juga mengajarkan bahasa Indonesia. Keenam institusi tersebut merupakan beberapa institusi tujuan di mana para pengajar BIPA yang ditugaskan oleh PPSDK akan mengajar BIPA selama satu semester. Nama-nama institusi tersebut didapatkan dari surat tugas yang dikeluarkan oleh PPSDK.

2. Motivasi Masyarakat Timor Leste belajar bahasa Indonesia

Bahasa Indonesia sangat berperan penting bagi masyarakat Timor Leste dan dari hasil wawancara yang dilakukan penulis dengan beberapa masyarakat Timor Leste, penulis mendapatkan informasi tentang motivasi mereka untuk belajar bahasa Indonesia. Berdasarkan data yang diperoleh (Tabel 3), terdapat empat alasan yang menjadi motivasi pemelajar Timor Leste mempelajari bahasa Indonesia sebagai bahasa asing. Motivasi tersebut adalah berkomunikasi, budaya, belajar dan bersosialisasi.

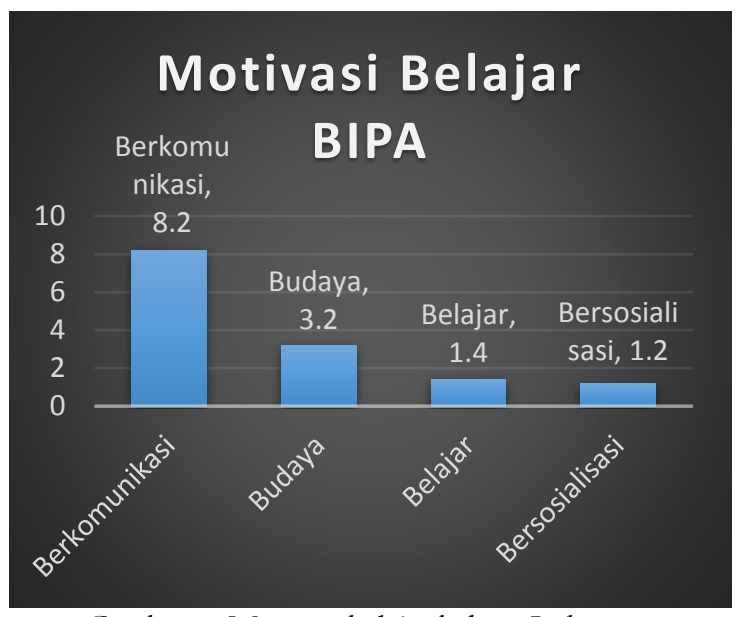

Gambar 3. Motivasi belajar bahasa Indonesia

Manfaat yang pertama adalah untuk berkomunikasi. Sebanyak 8,2\% responden berpendapat bahwa berkomunikasi menjadi andalan motivasi mereka untuk belajar bahasa Indonesia.
Bahasa Indonesia di Timor Leste sangat penting karena banyak warga negara Indonesia yang tinggal dan bekerja di Timor Leste. Selain itu, para pendatang yang datang ke Timor Leste untuk berdagang cenderung berbicara dalam bahasa Indonesia daripada dalam bahasa Tetun atau bahasa Portugis. Dengan menguasai bahasa Indonesia, masyarakat Timor Leste dapat berkomunikasi dengan para pedagang dan mendapatkan pekerjaan. Selain itu, mereka dapat berkomunikasi dengan orang lain yang berasal dari distrik yang berbeda.

Motivasi yang kedua adalah karena budaya. Siaran televisi Indonesia sangat diminati oleh masyarakat Timor Leste dan salah satu motivasi mereka untuk belajar bahasa Indonesia adalah supaya dapat memahami budaya Indonesia karena budaya Indonesia. Dengan mempelajari bahasa Indonesia, mereka dapat memahami budaya Indonesia yang mereka lihat di sekitar mereka atau yang mereka tonton melalui siaran televisi Indonesia.

Kesempatan belajar di Indonesia merupakan salah satu motivasi mereka untuk mempelajari bahasa Indonesia. Melanjutkan pendidikan ke jenjang yang lebih tinggi merupakan impian masyarakat Timor Leste dan Indonesia menjadi salah satu tujuan negara untuk menimba ilmu. Setiap tahunnya, pemerintah Indonesia melalui program beasiswa KNB dan Darmasiswa memberikan kesempatan bagi mereka untuk melanjutkan studi lanjut atau mengikuti program pertukaran mahasiswa di Indonesia. Bukubuku teks dan referensi yang digunakan di institusi pendidikan di Timor Leste sebagian besar berbahasa Indonesia. Tenaga pengajar di Timor Leste mayoritas merupakan lulusan dari perguruan tinggi yang ada di Indonesia. Pengalaman tenaga pengajar belajar di Indonesia, buku referensi yang berbahasa Indonesia, bahasa Indonesia sebagai bahasa pengantar dalam menyampaikan materi serta bahasa Indonesia digunakan untuk menulis tugas akhir menjadi motivasi responden untuk mempelajari bahasa Indonesia.

Dapat bersosialisasi merupakan motivasi terakhir yang mendorong responden untuk belajar bahasa Indonesia. Selain sebagai bahasa asing, bahasa Indonesia dipelajari sebagai bahasa kerja di Timor Leste. Tidak semua penduduk yang ada di Timor Leste mahir berbahasa Tetun atau Portugis. Selain itu, ada kemungkinan antara satu distrik dengan distrik yang lain memiliki bahasa yang berbeda. Penduduk di Timor Leste, seperti relawan internasional, warga negara Indonesia, pedagang dari Vietnam dan negara lain akan mempelajari bahasa Indonesia karena lebih mudah. Untuk bersosialisasi dengan mereka yang tidak berasal dari Timor Leste 
atau dari daerah yang sama, mereka menggunakan bahasa Indonesia.

\section{Upaya Pengembangan bahasa Indonesia di Timor Leste}

Tidak semua masyarakat Timor Leste mampu berbahasa Indonesia. Hanya mereka yang memiliki televisi dan atau pernah mendapatkan pelajaran bahasa Indonesia atau bahasa Melayu yang dapat berbicara bahasa Indonesia. Generasi muda Timor Leste yang berasal dari distrik dan pindah ke Dili untuk berkuliah belum bisa berbicara dalam bahasa Indonesia karena mereka menggunakan bahasa Tetun untuk berbicara di daerah mereka, serta kurangnya eksposure bahasa Indonesia di kehidupan mereka, seperti tidak ada siaran program televisi berbahasa Indonesia yang dapat mereka tonton di distrik mereka.

Hal ini berbeda dengan mereka yang tinggal di Dili. Bahasa Indonesia digunakan di tempat-tempat umum, seperti di pasar, pusat perbelanjaan, transportasi umum, warung makan, dan toko-toko. Selain itu, mereka yang tinggal di Dili memiliki akses untuk menonton program acara televisi berbahasa Indonesia. Program acara televisi berbahasa Indonesia memiliki peranan yang cukup penting dalam menyebarkan bahasa Indonesia di kalangan masyarakat Timor Leste.

Bahasa Indonesia juga digunakan sebagai bahasa pengantar di institusi-institusi pendidikan yang ada di Timor Leste. Berdasarkan wawancara dengan beberapa mahasiswa Timor Leste, mayoritas mengatakan bahwa mereka mendapatkan pelajaran bahasa Indonesia sewaktu mereka ada di Sekolah Menengah Atas (SMA) dan tidak mendapatkan pelajaran bahasa Indonesia di tingkat Sekolah Menengah Pertama (SMP).

Selain itu, sebagian besar pengajar-pengajar yang ada di Timor Leste berkuliah di Indonesia dan mereka kembali ke Timor Leste dengan menerapkan sistem pendidikan di Indonesia. Pengajar-pengajar tersebut menggunakan bahasa Indonesia sebagai bahasa pengantar dan menggunakan sumber belajar yang berbahasa Indonesia. Narasumber juga menyebutkan bahwa sebagian besar buku-buku yang ada di perpustakaan adalah berbahasa Indonesia, bukan bahasa Tetun atau bahasa Inggris atau bahasa Portugis. Bahkan, pada tahun 2016 masih ada beberapa universitas yang mengharuskan mahasiswanya untuk menulis skripsi menggunakan bahasa Indonesia. Namun pada tahun 2017, beberapa universitas sudah mengharuskan mahasiswanya untuk menulis skripsi di bahasa Tetun atau bahasa Inggris.

Dengan fenomena tersebut, bahasa Indonesia masih memiliki peluang untuk berkembang dan penuturnya akan semakin banyak di Timor Leste. Pemerintah Indonesia sudah memiliki Pusat Budaya Indonesia yang memberikan kursus bahasa Indonesia kepada masyarakat Timor Leste dan diplomatdiplomat yang ada di Timor Leste. Selain memberikan kursus bahasa Indonesia, Pusat Budaya Indonesia juga memberikan kesempatan bagi masyarakat Timor Leste untuk belajar budaya Indonesia, seperti bermain gamelan, angklung, dan tarian Indonesia.

\section{Simpulan}

Peran bahasa Indonesia di Timor Leste masih sangat besar, baik di bidang pendidikan ataupun perekonomian. Dengan masih banyaknya buku-buku pelajaran berbahasa Indonesia, bahasa Indonesia sebagai bahasa pengantar dalam menyampaikan materi pelajaran serta bahasa Indonesia sebagai bahasa kerja, maka

Berdasarkan pemaparan di atas maka dapat disimpulkan bahwa bahasa Indonesia memiliki peran yang sangat besar bagi perkembangan masyarakat di Timor Leste, terutama di bidang pendidikan.

Perlu adanya peran lebih pemerintah Indonesia dan organisasi sosial terkait untuk mengembangkan pengajaran bahasa dan budaya Indonesia di Timor Leste. Pemerintah juga perlu untuk melakukan pemutahiran data tentang institusi-institusi pendidikan yang ada di Timor Leste yang memiliki program bahasa Indonesia serta mengokohkan mata pelajaran bahasa Indonesia dengan nama bahasa Indonesia, bukan bahasa Melayu

\section{Persantunan}

Penulis berterima kasih kepada berbagai pihak yang telah memberikan dukungan kepada penulis dalam menyelesaikan artikel ini. Ucapan terima kasih kepada PPSDK yang telah menugaskan penulis untuk mengajar di Timor Leste dan teman-teman sejawat di Timor Leste. Semoga artikel ini dapat memberikan kontribusi dalam pengajaran dan Pengembangan BIPA di Indonesia dan di Timor Leste.

\section{Daftar Pustaka}

Almeida-Patricia Albergaria dan Mariana Martinho. (2014). The Empowerment of Education in East Timor through in-service teacher training. WCES Journal. (Diakses dari laman https://core.ac.uk/download/pdf/82035994. pdf pada tanggal I2 September 2018)

Badan Pengembangan dan Pembinaan Bahasa. (2009). Undang-undang Republik Indonesia Nomor 24 Tahun 2009 tentang Bendera, Bahasa dan 
Lambang Negara serta Lagu Kebangsaan. Jakarta: Kementerian Pendidikan dan Kebudayaan. (Diakses dari http://badanbahasa.kemdikbud.go.id/lamanba hasa/sites/default/files/UU_2009_24.pdf pada tanggal II September 2018)

Fox, J. J. dan Soares Dionisio. (2003). Out of the ashes: deconstruction and reconstruction of East Timor.Canberra: ANU E Press

Kusprabowo, Kiki T. (2008). Kondisi Terkini Pengajaran Bahasa Indonesia di Timor Leste. (Diakses dari laman

https://balaibahasakalteng.kemdikbud.go.id/w p-content/uploads/2016/12/Kondisi-TerkiniPengajaran-BI-di-Timor-Leste.pdf pada tanggal I I September 2018)

Maulipaksi Desliana. (2018). Bahasa Indonesia Jadi bentuk Diplomasi Indonesia dan Timor Leste. Laman Kementerian Pendidikan dan Kebudayaan. (Diakses dari https://www.kemdikbud.go.id/main/blog/20 18/07/bahasa-indonesia-jadi-bentukdiplomasi-indonesia-dan-timor-leste $\quad$ pada tanggal II September 2018)

Munady. (2016). Universitas di Timor Leste Masih Gunakan Bahasa dan Kurikulum Indonesia (diakses dari laman http://www.pikiranrakyat.com/luar-
negeri/2016/I2/3I/universitas-di-timor-lestemasih-gunakan-bahasa-dan-kurikulum-indonesia pada tanggal II September 2018)

Network, Development Studies. (2005). Development bulletin No. 68 October 2005: Cooperating with Timor Leste. Australia: Australia National University

Nirmalasari, Y. (2017). Laporan Pengiriman Tenaga Pengajar BIPA untuk Luar Negeri Program Pembelajaran Bahasa Indonesia bagi Pentur Asing di Institute of Business Dili, Timor Leste Masa Tugas 21 Juli - 10 Desember 2017. Jakarta: Pusat Pengembangan Strategi dan Diplomasi Kebahasaan (PPSDK)

Patricio, S. (2009). English as the needs of students of a public university in Timor Leste. Australian teacher Education Association (ATEA) Annual Conference Proceedings Archive. (Diakses dari https://files.eric.ed.gov/fulltext/ED524763.pd f pada tanggal I I September 2018)

Rejeki, S. (2017). Laporan Pengiriman Tenaga pengajar BIPA untuk Luar Negeri: Program Pembelajaran Bahasa Indonesia bagi Penutur Asing di Pusat Budaya Indonesia, Dili, Timor Leste masa Tugas 21 Juli - IO Desember 2018. Jakarta: Pusat Pengembangan Strategi dan Diplomasi Kebahasaan (PPSDK) 